\title{
The Spiritual Research of Yanshan-Taihang Mountain Poverty Alleviation Cadres under the Background of New Era
}

\author{
Siyu Feng * \\ Department of Law and Political Science, North China Electric Power University (Baoding), Hebei, \\ 071066, China \\ *1278634423@qq.com
}

\begin{abstract}
Eliminating poverty, improving people's livelihood, and gradually achieving common prosperity are the essential requirements of socialism. After more than 40 years of reform and opening up policy, China has embarked on a path of poverty alleviation with Chinese characteristics. In precise poverty alleviation, cadres in villages have become an important force to tackle the problem, and contact channels. Through studying the actual situation of the implementation of the basic strategy of the Party Central Committee's precise poverty alleviation in the concentrated and contiguous areas of Yanshan-Taihang Mountain, it is truly reflected in the successful examples of grassroots forces winning the battle against poverty under the strong leadership of party committees and governments at all levels. Finally, the research demonstrates the new era style of the vast number of poverty alleviation cadres stationed in the village taking up the role, dedicating to the grassroots, and making sacrifices on the battlefield of poverty alleviation.
\end{abstract}

Keywords: Cadre Administration; Poverty Alleviation; First Secretary.

\section{Development Dilemma of Yanshan-Taihang Mountain Poverty Stricken Area}

The Yanshan-Taihang Mountain area is one of the 14 concentrated contiguous destitute areas in China. Affected by natural, historical and other factors, the development of the area is lagging behind and deeply poor. The deeply impoverished areas of the three provinces are basically concentrated in this area. Compared with other contiguous destitute areas, the particularity of this area is that it is close to the Beijing-Tianjin megacity, and the reasons for poverty are more complicated due to the pressure of ecological protection policies and the siphon effect.

Since the 18th National Congress of the Communist Party of China, the relevant provinces in the area have increased their poverty alleviation efforts in all aspects. However, as the poverty alleviation efforts continue to deepen, the quality of the labor force is low, and the self-development ability is weak; the population is scattered and the level of urbanization is low; the industrial structure is backward and the economic development is stamina Insufficiency; fragile ecological environment and poor carrying capacity; difficulties and bottlenecks such as the prominent contradiction between ecological protection and development and production are becoming increasingly prominent. These problems are not only a manifestation of insufficient development, but also an obstacle to further development.

\section{The Current Situation of Poverty Alleviation at the Grass-roots Level}

As an important mechanism for precise poverty alleviation, cadre-resident assistance in villages has not only extensively mobilized the assistance forces within the administrative system through administrative forces, but also some enterprises and social organizations. Under administrative mobilization, a small-scale "government poverty alleviation + society" has been formed. The overall poverty alleviation pattern of "poverty alleviation" also demonstrates the advantages of the socialist system. Dispatching cadres not only solved the shortage of talents in poor areas, but also promoted poverty alleviation in poor villages through institutional and non-institutional assistance measures.

Since the 18th National Congress of the Communist Party of China, in order to consolidate and expand the effectiveness of poverty alleviation and solve the uneven development of urban and rural 
areas, the party and the government have taken poverty alleviation work for the poor and deeply impoverished areas as the bottom line task and landmark index for building a well-off society in an all-round way. As of 2020, a total of more than 775,000 cadres have been stationed across the country, and $97.6 \%$ of poor villages have been assigned first secretaries (195,000 first secretaries), and a total of 220,000 village task forces have been deployed. As a long-standing means of rural work, cadres' assistance in villages plays a positive role in widely mobilizing administrative and social forces, making full use of poverty alleviation resources and stimulating the endogenous motivation of poor objects. Therefore, it can be called the institutional innovation of poverty alleviation in China.

\section{The Path Exploration}

By analyzing the path direction of "political party government market society", this paper explores the leading core role of Party committees at all levels in taking the overall situation and coordinating all parties, combined with the construction of Grass-roots party organizations and poverty alleviation, so as to stimulate the endogenous driving force of poor groups and enhance the people's ability to extricate themselves from poverty.

\subsection{Fully Strengthen the Core Role of the Party's Leadership}

One is to highlight distinct political functions. The historical mission, historical status and historical orientation of the Communist Party of China determine that the Communist Party of China is the core force leading national construction and social development, the ruling party leading the people of the whole country to grasp political power and be in power for a long time, and the "central axis of contemporary China's political system". This is not only the scientific positioning and high consciousness of the CPC for the self-construction of the party subject, but also the conscious grasp of the coordinated promotion of governance and society.

The second is to strengthen top-level design and focus on policy coordination. As the leading core of the construction of socialism with Chinese characteristics, the Communist Party of China focuses on the goal of "two centenaries" and the Chinese dream of the great rejuvenation of the Chinese nation. All Party members and cadres should promote the overall layout of "five in one" and the strategic layout of "four comprehensives", raise the poverty alleviation strategy to the height of the national development strategy, carry out scientific top-level design, put forward correct principles and policies, and transform it into the national will.

\subsection{Strengthen Government Responsibility to Market and Society}

The first is to strengthen government responsibilities and strengthen government leadership. The government should change the traditional omnipotent role and actively guide social forces to participate in interest coordination. The government led by the role of omnipotence has the dilemma of multiple role conflicts in interest coordination; it actively guides the poor groups to participate in the interest coordination, and realizes the two-way interaction between the interest coordination subject and the object. Open poverty alleviation funds, project planning, etc. to the poor, while realizing the rights of the poor to know and supervise, promote the poor to fully understand all aspects of poverty alleviation, and integrate their interest demands and wishes into the system and policies for poverty alleviation.

The second is to improve and improve the participation mechanism of market players. Further develop and improve the platforms and carriers for market participants to participate. First, actively construct a financial support platform for market entities, and create a commercial, policy, development, and radiation financial poverty alleviation platform; and further develop market-based poverty alleviation development entities and enrich local financing vehicles. 


\section{Strengthen the Education of Marxist Ideology}

The first is to strengthen Marxist ideals and beliefs and build the soul of the Communist Party of China. Marxist education must be strengthened to a strategic height of consolidating the roots and condensing souls, guiding party members and cadres to deeply study Marxism-Leninism, Mao Zedong Thought, and the theoretical system of socialism with Chinese characteristics, and comprehensively study and comprehend the spirit of the 19th National Congress of the Communist Party of China, especially Xi Jinping's theoretical system of socialism with Chinese characteristics in the new era, the spirit of General Secretary Xi Jinping's series of important speeches, new concepts, new ideas, and strategies for governing the country and politics, using Marxist-Leninist positions, viewpoints, and methods to specifically study and analyze the socialism with Chinese characteristics, system theory, the development status and future prospects of the road of socialism with Chinese characteristics, strengthen the ideals and beliefs of Marxism in the turmoil of various thoughts at home and abroad, and strengthen the lofty ideals of communism and the common ideals of socialism with Chinese characteristics.

The second is to correctly establish the concept of "people-centered" power, and truly achieve the concept of "power is endowed by the people, sentiment is tied to the people, power is used by the people, and benefits are sought by the people". Strengthen the rational understanding of Marxist view of power. Establish a scientific "people-centered" concept of power in ideology, clean and selfdiscipline in behavior, promote the rule of law and standardization of the operation of public power, effectively curb the vicious expansion of public power, break the barriers of solidification of interests, and use state power and social power. The interaction promotes public power to be firmly in the hands of the people.

\section{References}

[1] Xiang Xin. Research on the path of the party's interest coordination from the perspective of poverty alleviation. Doctoral dissertation, The Party School of the CPC Central Committee, 2019.

[2] Yang Fang Thoughts on strengthening the construction of Township Party committee secretaries in the new era -- a case study of Zhuzhou County, Doctoral dissertation, Hunan Normal University,2012.

[3] Li Shufen. Research on the subject and mode of administrative accountability in China Yanshan University, Hebei Province. June 30, 2009.

[4] Yan Chen. Construction of positive incentive, fault tolerance and error correction mechanism for Party members and leading cadres from the perspective of comprehensively and strictly administering the party: logic and path. Journal of Zhuhai Administration College, Party School of the CPC Zhuhai Municipal Committee, 2018 (3): 29-37. 